\title{
The War on Drugs in Colombia: The Environment, the Treadmill of Destruction and Risk-Transfer Militarism*
}

\author{
Chad L. Smith \\ Texas State University \\ clsmith $a$ txstate.edu \\ Gregory Hooks \\ Washington State University \\ ghooks@wsu.edu

\section{Michael Lengefeld} \\ Washington State University \\ m.lengefeld@wsu.edu
}

\begin{abstract}
Ecological damage, including global climate change, is commonly connected to practices and behaviors associated with economic activity and the Treadmill of Production (ToP). Less attention is paid to the connection between the military and environmental degradation, but recently the Treadmill of Destruction (ToD) has been documented as a global phenomenon with negative environmental effects. The ToD directly and indirectly contributes to environmental problems on many fronts, but one of the least obvious means by which the U.S. military influences the environment is through its policies supporting the "war on drugs." The U.S. military aids Latin American countries, particularly Colombia, in the war on drugs in a number of capacities, including military support and training, weaponry, fumigation of crops, and logistical and surveillance support. The effort of the United States to curb the proliferation of illegal drug crops in Colombia is the most direct role that the military has played in this effort. Within the context of the "war on drugs" the United States is now engaged in risk-transfer militarism in which the consequences of this military action are borne by the Global South. We document the scope, magnitude, and consequences of the ToD in the war on drugs and the ways it negatively impacts the environment. Our argument reframes the ToD by emphasizing the role of risk-transfer militarism within the emergence of "new" wars as represented in the case of Colombia.
\end{abstract}

Keywords: Treadmill of Destruction, War on Drugs, Colombia, Climate Change, Risk-Transfer Militarism, "New" Wars 
In this article, we document the manner in which the militarized "war on drugs" waged by the United States contributes to environmental degradation in Colombia. The U.S. involvement includes military support and training, weaponry, fumigation of crops, and logistical and surveillance support. In addition to documenting the scope and magnitude of this militarized war on drugs in the Colombian Andes, we assess its impact on the environment, most notably with respect to deforestation and climate change. Our goals are two-fold: first, we pinpoint the spatial, historical, and social dimension of the treadmill of destruction in Colombia; second, we utilize the case of Colombia's war on drugs and its connections to the treadmill of destruction in order to contextualize several nascent developments, namely the emergence of risk-transfer militarism and the "new" wars of the $21^{\text {st }}$ century.

"Catastrophic convergence" (Parenti 2011) is the collision of multiple social, economic and environmental catastrophes (poverty, violence, climate change) playing out in the tropics of the Global South. Parenti describes the changing climate not only as the backdrop for these social and economic problems, but highlights an additional concern: climate change will exacerbate these problems and, thereby, produce a feedback loop. Parenti (2011:8) contends that "Cold War-era militarism and the economic pathologies of neoliberalism" paved the way for this catastrophic convergence. Failed states can offer little institutional resistance to and are further weakened and delegitimized by the emergence of illegal trading of guns and illicit drugs. We believe that this militarized war on drugs contributes to the convergence Parenti has identified. Although our focus is upon the environmental costs borne by Colombia, it is clear that states, worldwide, are undergoing a series of crises. Chase-Dunn (2013) identifies the global scale of this crisis, and although we do not directly address all five of his "linked crises" we do think this case is reflective of this larger set of dynamics Chase-Dunn identifies.

In the pages that follow we situate the treadmill of destruction within the context of failed and struggling states with particular attention on the history of conflict in Colombia. We address the environmental and social effects that coca cultivation and the production of cocaine has in Colombia and, in turn, how efforts to curb its production, primarily through the U.S. policy of "Plan Colombia," are problematic. As the metaphor of a treadmill suggests, the intensification of militarized drug production and destruction has resulted in an escalation of the accompanying environmental devastation. Finally, our argument reframes the treadmill of destruction by emphasizing the role of risk-transfer militarism within the emergence of "new" wars as represented in the case of Colombia.

\section{Treadmills, Environmental Damage, and Failed States}

The treadmill of production (ToP) is driven by commercial demands, primarily growth, market shares and profitability (Gould, Pellow and Schnaiberg 2008; Schnaiberg 1980; Schnaiberg and Gould 1994). The treadmill of destruction (ToD) is driven by the distinctive demands of geopolitics, militarism and war making. To highlight the distinctive effects of the ToD we begin with a discussion of the commercially oriented ToP stemming from the lucrative and globalized commodification of cocaine.

The ToP points to capitalist economic production as the driving force behind environmental damage. The treadmill refers to the relentless quest for economic growth and the high (and growing) levels of social inequality that result from this quest. With respect to the environment, the ToP makes unsustainable demands on the environment in the form of 
extraction of raw materials used in the production and distribution goods and in the form of waste.

When first developing the concept, Schnaiberg (1980) was largely focused on the United States. However, the ToP framework has been extended to shed light on processes operating at a transnational and global scale (Gould, Pellow and Schnaiberg 2008). Consideration of global commodity chains and the resulting unequal environmental exchange provides valuable insights into the transnational implications of the treadmill of production. Hopkins and Wallerstein (1982:159) define global commodity chains as "a network of labor and production processes whose end result is a finished commodity" (see also, Ciccantell and Smith 2009). Global commodity chains introduce demands from distant and powerful actors, disrupting and distorting local economic and social relationships, resulting in "unequal environmental exchanges" that impose steep environmental costs on vulnerable people and places (Rice 2007).

Clelland (2014), adopting a metaphor from physics, distinguishes between "bright" value and "dark" value. Physicists estimate that dark energy and dark matter account for the preponderance of the universe (more than 90\%). "By analogy, that invisible human and natural energy flows are converted into the dark value that forms part of the basic structure of the worldsystem" (Clelland 2014: 85). Dark value is added in the periphery-externalized to workers, communities, households and ecosystems. The United Nations' Office on Drugs and Crime (2010: 170) estimates that a markup of roughly 30 times between coca derivatives (in the Andean producer states) and cocaine wholesale prices in the United States, and even more, 60 times, in Europe. Only a small portion of the spectacular street value of cocaine (its "bright" value) is derived from the risk (street violence and incarceration) confronted by organized criminal organizations that distribute cocaine in the Global North. The many externalities ecological degradation and the coerced and undercompensated labor by Andean growers (cocaine's "dark" value) form the basis of cocaine's value. Ribot (1998), in a study of the commodity chain impacting Senegalese forestry, offers a reminder that securing access can be far more important than formal ownership in determining who profits. In the Andean regions of Colombia and especially the remote Amazonian regions where coca cultivation has spread in recent decades, access is often more important than nominal property rights. Without a formal title, squatters, guerrilla/paramilitary armies, and organized criminal networks take effective control of lands used for coca cultivation and coca processing. The prevalence of coercion in Colombian coca cultivation and processing contributes to the high rates of uncompensated negative externalities (unpaid labor by direct producers and ecological degradation), i.e., dark value.

The era of globalization - with the cheapening of transportation and communication made possible the commodification of cocaine in the late-20th Century. The coca plant is indigenous and well adapted to the Andean region. As such, coca could be cultivated with few deleterious consequences for the environment. But the commodification of cocaine has set in motion powerful treadmill dynamics, sharply unequal environmental exchange, and widespread damage to the environment. Exacerbating this impact, a large number of ecological hotspots in the region have been severely damaged. 


\section{The Treadmill of Destruction and the "New" Wars of the 21 st Century}

With a focus on the United States in the $20^{\text {th }}$ Century, Hooks and Smith $(2004,2005)$ introduced the "treadmill of destruction" by detailing the environmental dangers posed by the military. In this initial formulation, the understanding of the treadmill drew attention to the environmental degradation and inequality sustained by the world's leading military powers and fully professionalized military organizations. A number of scholars have extended the treadmill of destruction framework to consider its global reach (Clark and Jorgenson 2012; Jorgenson 2005; Jorgenson and Clark 2009; Jorgenson, Clark and Kentor 2010; Lengefeld and Smith 2013; York 2008). But this focus did not fully consider the growing ability of powerful nations to intervene in and shift the risk of war to less privileged peoples and less powerful nations. Moreover, this focus does not allow full consideration of the wars (and attendant environmental degradation) attributable to less formal (and less powerful) military organizations.

Arms races and wars generate and are sustained by a treadmill dynamic that is distinct from that driven by commercial competition. In the context of "old" wars (involving professionalized armed forces under the state's control), acquiring and controlling territory loom large. Military forces routinely degrade the territory controlled by opposing forces, and battlefields remain toxic long after peace is declared. To cripple the war-making potential of adversaries, military forces degrade the industrial and agricultural assets controlled by opposing forces; this routinely entails widespread, significant, and deliberate environmental degradation (Hooks and Smith 2005). To understand the environmental footprint of the "new" wars of the $21^{\text {st }}$ Century, the treadmill of destruction framework must be refined and updated. The world's most powerful nations are motivated to shift the risk of war to peoples and places of the Global South (Hooks and Smith 2012; Shaw 2002, 2005). At the same time, formal military organizations and the ability to sharply distinguish between combatants and noncombatants is less common in the "new" wars of the $21^{\text {st }}$ Century. Instead, a wide range of armed organizations (e.g., guerrilla armies, temporary militias and organized criminal organizations of various size and capabilities, etc.) is playing a prominent role (Kaldor 1999). Finally, the control of territory is typically less important in "new" wars. Nonetheless, the environment is often degraded as these wars are pursued. To generate revenue to support privatized and less formal war making, military forces pursue unsustainable production and extractive efforts and maintain predatory relations with direct producers. These irresponsible practices are fueled by arms races and military competition; as the ferocity and stakes of military conflict accelerate so do the treadmill dynamics and the attendant impact on the environment.

War-defined broadly as organized violence by Kaldor (1999) — is and has been a social activity that builds on and reflects extant social relationships and structures. In the $19^{\text {th }}$ and $20^{\text {th }}$ Centuries, the world's leading military powers maintained professionalized standing armies and navies. As such, waging war was monopolized by states and soldiers were sharply demarcated from the civilian population: "war made the state, and the state made war" (Tilly 1975: 142). The state as war maker remains intact for the United States and other major powers concentrated in the Global North. However, Shaw (2005) contends that the nations of the Global North, especially military powers such as the United States, are pursuing risk-transfer militarism. For the Global North, the homeland and citizens are shielded from the horrors of war and militarization because wars are fought on the terrain of vulnerable nations. If soldiers from the Global North are deployed, they fight from a distance, taking advantage of qualitatively superior military technologies. But the state's monopoly over violence is not guaranteed. In the new wars 
Table 1. New Wars and New Dynamics to the Treadmill of Destruction

\begin{tabular}{|c|c|c|c|}
\hline & & \multicolumn{2}{|c|}{ "New" wars } \\
\hline & "Old" wars" & Global Northb & Global South $^{\mathrm{a}}$ \\
\hline $\begin{array}{l}\text { Military } \\
\text { forces }\end{array}$ & $\begin{array}{l}\text { Professional } \\
\text { (standing) army } \\
\text { under the state's } \\
\text { control }\end{array}$ & $\begin{array}{l}\text { Professional forces under the } \\
\text { state's control with use of } \\
\text { mercenary forces to obscure } \\
\text { culpability }\end{array}$ & $\begin{array}{l}\text { State lacks monopoly on } \\
\text { means of coercion. Diverse } \\
\text { military forces operate. }\end{array}$ \\
\hline $\begin{array}{l}\text { Patterns of } \\
\text { violence }\end{array}$ & $\begin{array}{l}\text { Pitched battles, war } \\
\text { and peace demarcated } \\
\text { by formal treaties. } \\
\text { Soldiers suffer } \\
\text { highest casualty rates. }\end{array}$ & $\begin{array}{l}\text { Risk-transfer militarism, } \\
\text { military operations in Global } \\
\text { South without formal } \\
\text { declaration of war. Suffer very } \\
\text { few casualties while relying on } \\
\text { high-tech weaponry to inflict } \\
\text { heavy losses on adversaries. }\end{array}$ & $\begin{array}{l}\text { Violence deployed to achieve } \\
\text { a variety of ends, including } \\
\text { income generation, } \\
\text { intimidation and genocide. } \\
\text { Noncombatant casualties far } \\
\text { exceed casualty rates among } \\
\text { soldiers. }\end{array}$ \\
\hline $\begin{array}{l}\text { Financing } \\
\text { violence }\end{array}$ & $\begin{array}{l}\text { State taxation; state } \\
\text { plays prominent role } \\
\text { in fiscal management } \\
\text { of economy }\end{array}$ & $\begin{array}{l}\text { State taxation supports } \\
\text { interventions by nations of the } \\
\text { Global North; aid provided to } \\
\text { allied but failed states in the } \\
\text { Global South. }\end{array}$ & $\begin{array}{l}\text { Legitimate economy often } \\
\text { collapses. Predation by armed } \\
\text { forces on non-combatants: } \\
\text { resource exploitation, } \\
\text { kidnapping, extortion, and } \\
\text { protection rackets. }\end{array}$ \\
\hline $\begin{array}{l}\text { Spread of } \\
\text { violence }\end{array}$ & $\begin{array}{l}\text { Battlefields where } \\
\text { professionalized } \\
\text { armies and navies } \\
\text { encounter one } \\
\text { another. In "total" } \\
\text { war, industrial } \\
\text { infrastructure and } \\
\text { population centers } \\
\text { become "legitimate" } \\
\text { targets. }\end{array}$ & $\begin{array}{l}\text { Global North intervenes } \\
\text { indirectly or uses weapons that } \\
\text { minimize risk to own troops. } \\
\text { Rhetorical strategies deflect } \\
\text { responsibility for violence and } \\
\text { aftermath. }\end{array}$ & $\begin{array}{l}\text { No clear spatial demarcation. } \\
\text { Pockets of peace in violent } \\
\text { regions; pockets of violence in } \\
\text { peaceful areas. Armed forces } \\
\text { extend zone of conflict; } \\
\text { noncombatants relocate to } \\
\text { more remote areas in search of } \\
\text { safety. }\end{array}$ \\
\hline $\begin{array}{l}\text { Treadmill } \\
\text { of } \\
\text { destruction }\end{array}$ & $\begin{array}{l}\text { Highly toxified } \\
\text { battlefields; weapons } \\
\text { manufacture } \\
\text { environmentally } \\
\text { destructive. In total } \\
\text { war: wide-spread } \\
\text { destruction of major } \\
\text { cities and degradation } \\
\text { of infrastructure. }\end{array}$ & $\begin{array}{l}\text { Wars and attendant } \\
\text { environmental impacts shifted } \\
\text { to Global South. Decisions to } \\
\text { degrade environment and to } \\
\text { deploy environmentally } \\
\text { irresponsible weapons (e.g., } \\
\text { uranium tipped projectiles) } \\
\text { and tactics (e.g., aerial } \\
\text { dispersion of herbicides). }\end{array}$ & $\begin{array}{l}\text { Rapacious extraction of } \\
\text { natural resources to finance } \\
\text { military operations; } \\
\text { toxification of ecosystem to } \\
\text { deprive enemy of resources } \\
\text { and sanctuary. }\end{array}$ \\
\hline
\end{tabular}

${ }^{\text {a }}$ Source: Mary Kaldor (1999). New and Old Wars.

${ }^{\text {b }}$ Source: Martin Shaw (2005). The New Western Way of War. 
of the $21^{\text {st }}$ Century, especially those fought in the Global South, a wide range of armed groups wage war. Instead, these wars "are characterized by a multiplicity of types of fighting units both public and private, state and non-state, or some kind of mixture" (Kaldor 1999: 92) of these various combinations of combatant units. In turn, the environmental degradation and inequality resulting from war - the treadmill of destruction - varies with the manner in which military forces are organized, how they are financed and the manner in which battles are fought. Table 1 summarizes key features of the "new" wars of the $21^{\text {st }}$ Century and the environmental implications.

The Colombian case brings into sharp relief the new forms of war and associated assaults on the environment. As will be discussed in greater detail below, there have been a wide range of military forces operating in Colombia, including the Colombian military, organized criminal organizations, paramilitary forces allied with the government, anti-government guerilla forces, and a variety of less formal and more transient (but still armed) fighting forces. The United States has participated directly and indirectly in this conflict, minimizing the risk to the United States' territory and personnel, while heightening the scale of violence in Colombia and surrounding countries. In Colombia, patterns of violence diverge markedly from those characteristics of "old" wars. Instead of pitched battles among formally organized and statecontrolled military units, violence is widely dispersed, sustained battles have been rare, and the violence has often involved efforts to generate revenues from illegal activities (especially coca and cocaine) and efforts to suppress the drug trade. The financing of this violence is also distinctive relative to "old" wars. The Colombian military forces have been financed through taxation, but the United States has also played a prominent role by providing sizeable military aid and by directly participating in drug eradication and counterinsurgency efforts. Especially in drug-producing areas, income generated from illegal activities often surpasses revenues from legal businesses. In predatory fashion, the diverse fighting forces have fought to control and/or profit from these illegal activities (e.g., extraconstitutional taxation and a variety of protection rackets). The resulting environmental degradation - the treadmill of destruction - reflects the specific forms of warfare. The predation of armed forces leads to unsustainable coca cultivation and cocaine production processes. The widespread conflict (both in number of casualties and in the spatial dimensions) and the disproportionate harm imposed on noncombatants results in dislocation of those caught in the crossfire. This contributes to accelerated deforestation and rapid degradation of lands newly brought under cultivation. The United States, in calculated fashion, amplifies these dynamics. Most notably, the U.S. commitment to crop eradication and other forms of military aid escalates the scale of violence confronting noncombatants and amplifies the environmental degradation.

While our focus will center on environmental degradation, the human suffering is staggering. In the context of widespread, low-tech and disorganized skirmishes, the civilian population is often treated harshly, including rape, dismemberment, kidnapping, and coerced conscription. Between 1990-2012 over 10,000 Colombians were victimized by landmines in 31 of 32 departments, an issue further exacerbated by humanitarian displacement crisis that is second only to the Sudan (Ballvé 2013; United Nations Human Rights Council 2013). From 1945-2000, at the global level, roughly 41 million people died due to armed conflict (Leitenberg 2006); a disproportionate number of wars and casualties occurred in the nations of the Global South (Summerfield 1991). More alarming still, noncombatants bear the brunt of this violence. Civilian deaths comprised roughly $5 \%$ of all deaths in World War I, but by the end of the $20^{\text {th }}$ Century, civilians suffered roughly $90 \%$ of all deaths in war (Summerfield 1991: 159). Thus, it 
appears that $21^{\text {st }}$ Century warfare will exacerbate a host of social and environmental problems (crime, war on drugs, climate change), and the consequences for the civilian population will be disastrous.

\section{The Treadmill of Destruction in Colombia}

The violence and conflict in Colombia has a long history, with much of it characteristic of "new" wars. As Guerrero Baron and Mond (2001:13) assert, "there is consensus that great social inequality and instability give rise to a dynamic that confers legitimacy on revolutionary projects and violent alternatives." The weak Colombian state lacked a firm monopoly on the means of violence long before the rise of guerilla armies, paramilitary groups and highly armed drug cartels (Holmes et al. 2008). The topography of Colombia and the longstanding history of regional and interdepartmental violence contributed to the Colombian state's weakness in the late $20^{\text {th }}$ Century. Colombia has a poor land transportation and communication infrastructure, lacking both roads and railroads; river transportation continues to be of central importance (Holmes et al. 2008). The decentralized state, poor infrastructure, rugged topography, and geographic isolation of independent regional powers set the stage for intensified violence.

Beginning in the 1940 's the Colombian people have endured political upheaval and civil war. Following the volatile years labeled as "la Violencia," rural lands became concentrated in the hands of Colombia's elite (known as the National Front agreement). In the 1960s, revolutionary peasant forces, such as the Revolutionary Armed Forces of Colombia (FARC), rejected the heightened inequality and challenged the state's legitimacy (Brittain 2010). In the context of the Cold War and in the shadow of the Cuban Revolution, the United States actively participated in counterinsurgency efforts. "Operation Marquetalia" (1964) was a joint US/Colombian operation that foreshadowed the weapons and tactics that would be featured in Vietnam, including the use of napalm; the effort cost roughly $\$ 3$ billion (in inflation adjusted dollars) and though it was interpreted as a success by the Colombian government, this military action served as a rallying point for peasant forces (Brittain 2010). In subsequent decades (1970s-1980s) FARC increased its presence across the country, and by 1990 it had become a powerful force in and of itself. Wickham-Crowley (1992) emphasizes the expansion of modern capitalist agriculture -- especially commercialized coffee production -- to explain the growing peasant support for the FARC.

From these revolutionary origins, FARC moved in the direction of a "narco-guerrilla" organization. While the specificity of Colombia's history shaped this transformation, it is also characteristic of the "new" wars of recent decades (see Table 1). FARC and other left-leaning guerrilla forces taxed drug organizations in the regions under their control and used the funds to finance military and political activities (Peceny and Durnan 2006; Saab and Taylor 2009; Holmes et al. 2008; Stokes 2001, 2005). Even as FARC became directly involved in coca cultivation and cocaine manufacture, it attempted to preserve its political objectives "by manipulating the conventional coca industry in the hopes of strengthening sociopolitical and economic conditions for the marginalized" (Brittain 2010: 89).

Even though the U.S. war on drugs officially began under the Nixon administration in 1969 , it genuinely began when the Posse Comitatas Act of 1878 was amended in 1981 to allow the Department of Defense (DoD) to mobilize the military in domestic legal threats, namely illicit drug trade (Ronderos 2003). With this legal backing, the Reagan Administration deemed 
the drug trade a national security threat and began employing military personnel and equipment to combat drug trafficking at the point of production (Bagley 1991). The militarization of the war on drugs is reflected in budgeting trends. In 1981, Congress allocated no funding to drug interdiction efforts, but by 1987 Congress allocated upwards of $\$ 379$ million to such efforts (Bagley 1991; Mabry 1988). As the war on drugs became synonymous with military intervention, some influential leaders in the Pentagon voiced concerns (Mabry 1988; Zirnite 1997). In 1985 Secretary of Defense, Caspar Weinberger, argued that "reliance on military forces to accomplish civilian tasks is detrimental to both military readiness and the democratic process" (Zirnite 1997: 8). These reservations notwithstanding, a rapid militarization of the war on drugs ensued culminating in "Plan Colombia."

"Plan Colombia" originated with Colombian President Andres Pastrana in 1998 (Scott 2003). The Clinton and Bush Administrations used the claim that military training and engagement would improve Colombia's human rights climate to justify U.S. military involvement. Even though the human rights situation has seen little improvement since the initiation of this policy (Vaicius and Isacson 2003), Plan Colombia was supported, and at times expanded, by the George W. Bush administration and the Barack Obama administration. Between 2000-2010, under the auspices of Plan Colombia (and related programs), more than $\$ 7$ billion in aid flowed to Colombia (Congressional Research Service 2011); only Israel and Egypt received more military aid over this time period (Buxton 2006).

Pastrana's original plan included military components, but it placed considerable emphasis on development. Buxton (2006) argues that the U.S. government reworked the effort into a highly militarized "battle plan" and that Pastrana "bypassed or ignored" agencies charged with maintaining checks on presidential power and a number of elected officials had no opportunity to provide input as Plan Colombia was revised and implemented (Buxton 2006). The revised Plan Colombia expanded aerial spraying of defoliants and authorized U.S. support of interdiction efforts by the Colombian National Police. The Plan also included limited support for development programs and social justice reforms (Messina and Delamater 2006). But it must be borne in mind that roughly $80 \%$ of Plan Colombia outlays supported military operations. The sharp discrepancy between U.S. spending on coca eradication (\$205 million) and economic development (\$72 million) in Colombia for 2006 (Davalos, Bejarano, and Correa 2009) underscores the military emphasis in the policy. Thus, Plan Colombia was in large measure "a military offensive aimed at debilitating Colombia's powerful rebel groups and aerially fumigating the abundant coca and poppy crops" (Mugge 2004: 311).

Plan Colombia was adopted in 2000. In the following decade, the production of cocaine (and import into the United States) increased significantly. Furthermore, FARC and other leftleaning forces remained potent (relying on revenues generated through the drug trade to support military efforts). These failures were compounded by right wing paramilitary groups (promoted and/or condoned by the Colombian government to counter left-leaning insurgents) becoming major players in the drug industry. In short, the Colombian drug economy continued to expand and thrive (Scott 2003), thereby legitimizing FARC as a governing body and accepted taxation system throughout much of the coca producing region. FARC and its supporters would highlight that its involvement in coca cultivation and drug processing was more benign than alternatives (organized criminal organizations and rightwing paramilitary organizations). Regardless of which armed force was in control, the division between public and private and the distinction between military and civilian was obscured; coercion lay at or near the surface of coca cultivation and sale. In terms of treadmill of destruction dynamics, coca cultivation and drug 
manufacture became an indispensable source of revenue to support military operations, leading to widespread adoption of environmentally irresponsible practices.

The links between the drug trade and the financing of war insured far-reaching environmental degradation in Colombia. These treadmill dynamics were amplified by U.S. policies, especially those premised on risk-transfer militarism. To obscure its far-reaching interventions and complicity, the United States sought to distance itself from the ugly consequences of Plan Colombia and maintain good standing within the international community by utilizing "surrogacy" (Bonds 2013). Technically speaking, U.S. policy only provides material support to the Colombian military by supplying helicopters, weapons, communications equipment and technology, infrastructure (i.e. building roads), and training (Mugge 2004). The Colombian government has allied itself (openly and covertly) with paramilitary forces. These paramilitary forces, at different times, have been both a legal and extra-legal means of confronting the left-leaning revolutionary force of FARC. The collusion of paramilitary factions with the Colombian military has convinced many analysts that these forces receive some share of the U.S.-sponsored equipment and training (Mugge 2004). It has been estimated that these paramilitary forces account for roughly 3,000 civilian casualties per year in Colombia (Mugge 2004; see also, Dube and Naidu 2010). Although the full range of U.S. involvement is cloaked in secrecy, the available evidence suggests that the United States is playing an active role. Priest (2013) reports that the Colombian military used Raytheon-produced smart bombs (weapons closely controlled by the U.S. Central Intelligence Agency) against FARC leader Raul Reyes inside Ecuadorian territory. This violation of Ecuadoran sovereignty sparked both a military and diplomatic crisis in 2008, leading to the deployment of Venezuelan and Ecuadorian troops on the Colombian frontiers. Ecuador filed lawsuits with the International Criminal Court and the InterAmerican Commission on Human Rights against Colombia, claiming human rights violations related to violence and coca eradication efforts (both lawsuits were eventually dropped by Ecuador).

Colombia provides an unusually valuable lens in the tragic face of contemporary warfare. If we use Kaldor's (1999) definition of war - i.e., organized violence - Colombia has been enduring war for more than 50 years. In recent decades, this warfare has displayed the distinctive pathologies of the "new" wars. Internal to Colombia, powerful criminal organizations, leftleaning insurgent forces and rightwing paramilitary forces have tapped into the lucrative drug trade to finance war efforts (directly and indirectly) and to sustain a highly corrupt and coercive economy. In his context, the state's monopoly over the means of violence and its legitimacy is eroded. These dynamics are amplified by the direct and cynical involvement of the world's leading military power (Bejarano and Pizarro 2005; Hough 2011). The increased militarization of the Colombian government not only led to the degradation of Colombian democracy (Bejarano and Pizarro 2005), but it simultaneously motivated FARC and other guerilla armies to adopt more repressive treatment of the local population and, ultimately, to engage in "state like" activities such as war making, state making, extraction, and protection (Hough 2011). Although Plan Colombia was pursued under the apolitical banner of an anti-narcotics effort, it is clear that the United States actively supported the Colombian state's attempts to rid the country of leftleaning revolutionaries. As Buxton (2006: 186) points out: "Given the power and influence that the USA had over the Colombian government at the time, it is open to question how far the Colombian president would have been able to resist U.S. eradication plans and strategies." Colombian officials were not merely on the receiving end of arm-twisting. Colombia benefitted from this relationship and used resources flowing from Plan Colombia to weaken revolutionary 
challengers. The United States insulated its personnel and its homeland from the ravages of this prolonged war. The human costs were disproportionately borne by noncombatants, the environmental impacts were concentrated in some of Colombia's (and the world's) most ecologically diverse but vulnerable lands and resources.

\section{The Environmental Consequences and Human Risks of the War on Drugs in Colombia}

The "new" wars of the $21^{\text {st }}$ Century continue and accelerate a disturbing trend: casualties among noncombatants far surpass those suffered by armed military forces. Casualties are inflicted - including a growing tolerance for casualties among noncombatants - where instrumental calculations point to strategies and tactics that achieve military objectives including a high casualty rate among noncombatants (even if inadvertent). The risk-transfer militarism adopted by leading military powers insures such outcomes. As is the case with other affluent nations of the Global North, the United States' overarching objective is to eliminate threats to the homeland and minimize casualties suffered by its own troops. Transferring risks and casualties to people (including noncombatants) and places in the Global South is inherent in this approach to warfare. Shaw (2005) points out that "small massacres" are inevitable and predictable in risktransfer militarism. That is, when relying on high-tech weapons to fight from a distance, it is inevitable that errors in target selection and guidance systems will result in innocent people being hurt and killed. Because the overarching goal is to transfer risks, the United States accepts this trade-off between "small massacres" and remarkably low casualty rates among its soldiers.

The treadmill of destruction sheds light on the manner in which this extends to ecosystems and environmental systems. Just as the United States is willing to accept the loss of human life that occurs in "small massacres," it is also willing to accept the degradation of the environment to achieve national security objectives. Of course, this is in the context of risktransfer militarism. By the same token, the predation of the various military forces operating in Colombia is not limited to acceptance of human suffering. Environmental resources and ecosystems are also squandered and sacrificed to support the war effort. This includes irresponsible and unsustainable cultivation techniques; it also includes the deliberate toxification of the environment to punish and constrain adversaries. Cocaine's "dark value" (Clelland 2014) includes both human and environmental casualties on a tragic scale.

\section{Environmental Degradation as a Military Tactic}

The links between environmental degradation and the cocaine trade begins with cultivation practices and the processing of coca leaves. As Bunker (2005) reminds us, transportation and energy demands are integral to cultivation decisions and infrastructure. Coca leaves are bulky, requiring 250-500 kilograms of dried leaves to produce one kilogram of cocaine. Coca paste can and is consumed in the region. For cocaine manufacture, it is an intermediate product: $250-500$ kilograms of dried leaves yields 2.5 kilograms of coca paste, depending on content of leaves and specifics of processing (Dombey-Moore, Resetar and Childress 1994). Transporting coca leaves, a bulky commodity, in the context of rugged topography and poor infrastructure would be quite costly. More to the point, coca leaves are also illegal and valuable. Transporting a large quantity of leaves over long distances risks detection by government officials and theft by armed forces operating in the area. For this reason, coca paste is typically fabricated near areas of cultivation, a process that is toxic for humans and damaging to ecosystems. The chemicals used include 
organic solvents (e.g., kerosene and diesel fuel), sulfuric acid, and potassium carbonate (InterAmerican Drug Abuse Control Commission 2005). The fabrication process consumes and contaminates a great deal of water, resulting in pollution of streams in the area (Mejía and Posada 2008). Reflecting the treadmill of destruction dynamics, producers are driven to maximize harvests as soon as possible and anticipate that coca plants will be eradicated within years of initial planning. For these reasons, heavy and unregulated use of herbicides, fertilizers and insecticides is common. The runoff from these agricultural chemicals further degrades water resources and compounds the environmental harm.

Just as the military forces involved in coca cultivation and cocaine manufacture adopt calculated policies that lead to environmental degradation, so too do those attempting to suppress drug production. The War on Drugs in Colombia relies heavily on spraying herbicides. Neither the United States nor Colombia discloses the specific mixture being used, but most experts agree that some version of Monsanto's glyphosate (i.e. "Roundup") is the base herbicide, but it is mixed with a locally manufactured surfactant, Cosmo-Flux 411 (Mugge 2004; Messina and Delamater 2006). The practice of aerial eradication is a joint operation involving the Antinarcotics Directorate of the Colombian National Police (DIRAN) and the National Affairs Section (NAS) housed at the U.S. Embassy in Bogota (Mugge 2004).

The secrecy surrounding the eradication effort makes it impossible to determine the specific form of glyphosate being used. This is unfortunate because impacts vary with the concentration and specific chemical composition in use (Mugge 2004). In addition, the content of the surfactant is also unknown. All that is known about this chemical is that it is produced in Colombia, where fewer environmental regulations are in effect (Mugge 2004). Regardless of the specific chemicals being used, there is clear and compelling evidence that the use of these herbicides, as practiced in Colombia, would violate regulations in place in the United States (Mugge 2004). In Colombia, glyphosate is being delivered via aerial fumigation from a height of 15 meters (49 feet), but the Environmental Protection Agency requires that it be applied at a height of 3-10 meters (10-32 feet) away (Alvarez 2001b; Buxton 2006). Similarly, the recommended dosage of glyphosate is approximately 2.3 liters/hectare $(0.60$ gallons/hectare $)$. In Colombia, it is being applied at five to ten times the recommended concentration (23.7 liters/hectare or 6.26 gallons/hectare) (Alvarez 2001b; Buxton 2006).

With few exceptions (Solomon 2007, 2009), a large body of research points to negative environmental impacts from these eradication efforts. These negative impacts include adverse effects for amphibians (Meza-Joy, Ramirez-Pinilla, and Fuentes-Lrenzo 2013; Relyea 2005a, 2005b, 2011; Solomon 2007, 2009), rats (de Liz Oliveira Cavalli et al. 2013) and mice (Jasper, Locatelli, Pilati, Lcatelli 2012). Numerous on-the-ground reports point to the environmental damage attributable to these herbicides (Messina and Delameter 2006; Mugge 2004). While the evidence of environmental impacts is compelling, claims that the eradication program is having the desired effect of decreasing coca production are disputed. During the first ten years of Plan Colombia, there was little evidence that cocaine production suffered. Over the last several years, sharp reductions are in evidence. The Office of National Drug Policy (2012) reports that that cocaine production capacity in Colombia has declined 25\% between 2010-2011. Likewise, the United Nations reports that the total area under coca cultivation in Colombia fell by one-quarter in 2011 (United Nations Office on Drugs and Crime 2012b). Although the recent evidence seems to indicate some decrease in coca production in Colombia, it is less clear that this is reducing the overall amount of cocaine available on world markets. It appears that coca cultivation and 
cocaine manufacture is shifting to other Andean nations, resulting in what is commonly referred to as the "balloon effect" (The Economist 2013; Hellin 2001).

The broader environmental consequences of these eradication policies include deforestation, contamination of water and water systems, eradication of non-coca crops and natural vegetation, and a generally negative impact on the biodiversity of the region (Alvarez 2002; Armenteras et al. 2006; Davalos et al. 2009; Davalos et al. 2011; Etter, et al. 2006; Fjeldsa et al. 2005; Messina and Delameter 2006; Mugge 2004).

\section{Human Risks}

Research indicates that glyphosate has negative consequences for human cells (Benachour and Seralini 2009) and human cell lines (Gasnier et al. 2009), that it induces insidious diseases in humans (Samsel and Saneff 2013) and promotes breast cancer growth in humans (Thongprakaisang et al. 2013). In the effected regions, villagers, farmers, and health care specialists have complained of skin illness, eye irritation, vomiting, diarrhea, and miscarriages (Mugge 2004; Transnational Institute 2001). The United Nations, Office of the High Commissioner for Human Rights (2010) considers these reports to be "credible and trustworthy." Although millions of dollars are budgeted to pursue this militarized war on drugs, no funds have been committed to examine these persistent complaints. As is characteristic of the treadmill of destruction, still another risk is transferred to the Global South: to protect the U.S. population from "unsafe" drugs, the people of Colombia are being subjected to environmental dislocation and heightened health impairment. In previous research, Hooks and Smith $(2004,2012)$ focused on the environmental legacy of weapons (conventional and nuclear) used in the $20^{\text {th }}$ Century's mass industrial wars and the ensuing Cold War. In the new face of militarism in the $21^{\text {st }}$ Century, the most severe impacts on the environment and human health stem from chemical warfare waged on the people and places thought to be involved with coca cultivation.

Without providing details about specific chemicals, quantities and locations, the U.S. State Department acknowledges reliance on glyphosate; explanations of "defensive categorization" are used to justify its use (Bonds 2013). That is, the United States downplays adverse impacts of controversial (potentially illegitimate) military tactics by disputing and minimizing the harm they cause. Spraying in Colombia has been denounced by a wide range of critics in Colombia, throughout Latin America and around the world (Buxton 2006). The State Department describes Cosmo-Flux $411 \mathrm{~F}$ as "essentially a soap that enhances the ability of the herbicide to penetrate the waxy cuticle of the leaf surface" (U.S Department of State 2002). Deflecting criticisms, the Department of State asserts that Cosmo-Flux $411 \mathrm{~F}$ is only "lightly toxic." The State Department also claims that glyphosate is safe because it is "one of the most widely used agricultural herbicides in the world" (U.S Department of State 2002). In similar fashion, although failing to meet EPA guidelines in this regard, the State Department emphasizes the dilution of chemicals used for eradication to downplay reports of harm to human health:

...the irritation and toxicity potential of the individual ingredients are reduced when diluted during mixing (the final product is approximately 75 percent water) and the mixture is dispersed when sprayed.... The symptoms of such exposure are likely to be short-term and reversible. (U.S. Department of State 2002). 
The U.S. government does acknowledge widespread environmental degradation in cocagrowing regions yet emphasizes the irresponsible environmental practices of peasants and military forces involved in coca cultivation and cocaine fabrication. "Over the past 20 years, coca cultivation in the Andean region has resulted in the destruction of at least 5.9 million acres of rainforest - an area larger than the states of Maryland and Massachusetts combined" (United States Department of State 2003). This report offers an extended discussion of the toxic chemicals and herbicides and reduction in biodiversity due to coca production; it goes on to discuss the implications for climate change. But, the Department of State makes no mention of its own emphasis on militarized eradication and how this amplifies the environmental impact of coca cultivation and cocaine manufacture. Relying on the rhetorical strategy of "defensive categorization" (Bonds 2013), the United States obscures its own role in the social and environmental disruption and shifts all responsibility to Colombians.

\section{Environmental and Ecological Damage}

Given that Colombia houses the largest number of bird species in the world and the second highest number of plant species in the world, the global implications of these developments are significant. Fjeldsa et al. (2005) find that biodiversity has decreased in the Andes (particularly in the Colombian Andes) due to the convergence of drug markets, decades of military conflict, and a paucity of economic alternatives for the rural poor in these regions (see also Alvarez 2002). In addition, crop eradication efforts are impacting water supplies and aquatic ecosystems. Monsanto acknowledges that glyphosate can have far-reaching impacts upon water quality and aquatic life. The assault on biodiversity extends to species that rely on water resources that are being compromised by coca cultivation and militarized eradication efforts (Mugge 2004). To date, neither the United States nor the Colombian government has undertaken a thorough study of the damage. Moreover, because neither government will provide detailed information on the extent and chemical composition of the herbicides deployed, independent researchers have been stymied as well.

The eradication of coca plants has had "the unintended consequence of defoliating not only coca but also contiguous and interspersed native forest and food crop parcels" (Messina and Delamater 2006: 127). Banana, corn, and yucca crops suffer when glyphosate is applied (Mugge 2004). This, in turn, has two consequences. In some cases, farmers return to growing coca to compensate for the loss of legal crops (banana, corn, yucca). Second, many farmers turn to forested lands to begin anew. Thus, the eradication program pushes farmers to increase the land under cultivation and, thereby, accelerates deforestation. As farmers are forced to continually move into forested lands - often remote, frequently part of forest reserves - for the purpose of crop production, whether that be for coca production or subsistence farming, there is both an increase in the release of carbon dioxide (cutting down the forest) and a subsequent loss of carbon sink (annual crops are a less effective carbon sink than forests).

Deforestation is on the rise and is threatening important aspects of biodiversity value (Armenteras et al. 2006; Etter et al. 2006). Drug eradication is not the only cause of deforestation. Deforestation has been linked to the presence of pasture and agricultural lands, distance to roads and cities (Armenteras, Rodriguez, and Retana 2013; Eraso, Armenteras-Pascual, Alumbreros 2012), colonization and population (Etter et al. 2006), and forestry export flows (Shandra, Leckband, and London 2009). Coca cultivation and eradication efforts intensify pressure on Colombia's forests. Coca cultivation is concentrated in the "coca belt" of southern Colombia 
(International Crisis Group 2005). This area is comprised of a low altitude humid forest wherein the cultivators of coca destroyed roughly 3.45 million acres of land between 1990 and 2000 (Buxton 2006). According to a report prepared by the Transnational Institute (2001), deforestation is a direct effect of the fumigation efforts sponsored by the U.S. military. Indiscriminate aerial herbicide spraying kills not only coca crops, but also food and alternative crops that are being promoted to reduce farmers' dependence on coca crops (Tenenbaum 2002). As coca crops are destroyed, the rural people migrate deeper into the rainforests or up the mountains to maintain their livelihood. Because "slash and burn" planting techniques provide the main method of farming in Colombia the result is increased rainforest destruction (Transnational Institute 2001; see also Achard et al. 2002; Nobre, Sellers, and Shukla 1991). Davalos et al. (2009: 382) concur, taking into consideration both the irresponsible practices used to cultivate and process coca and the damage caused by militarized eradication efforts, they conclude that "[c]oca is the single most important driver of deforestation in the country."

Alternative development initiatives meant to curb coca production have similarly exacerbated deforestation. Young (2004) observes that new road construction contributes to the spread of coca cultivation. Transportation improvements facilitate the acquisition of agricultural inputs, the purchase of chemicals for coca refinement, and shipment of coca leaves and coca paste. "Without exception, the current coca-growing areas are past tropical forest colonization projects... this began in the 1960s and continued into the 1990 s despite a near universal failure of these projects" (Young 2004: 365). Foreign assistance offered to drug "source" countries typically includes funding for alternative development initiatives and infrastructural enhancements. Road construction requires the bulldozing of tropical forest areas and typically includes the circumvention of environmental protection mandates. In turn, these new and improved roads facilitate illicit drug production by providing a more reliable and cheaper transportation and access to remote forest regions (Young 2004). ${ }^{1}$

While the social and environmental damage of Plan Colombia was immediate, the effects on coca suppression were mixed and slow to emerge. In the initial years of implementation, this militarized war on drugs may have contributed to expanded coca production in Colombia and other Andean nations After the adoption of Plan Colombia, the number of coca-growing provinces in Colombia increased from 12 to 23 (United Nations Office of the High Commissioner for Human Rights 2010). Furthermore, roughly $42 \%$ of the land under coca cultivation between 2001-2011 is on land that was "formerly covered by forests" (United Nations Office on Drugs and Crime 2012a). The local and global environmental consequences of this are staggering as the local population relocates to more remote lands and releasing $\mathrm{CO}_{2}$ as forests are sacrificed to coca cultivation.

\footnotetext{
${ }^{1}$ Two important topics are beyond the scope of this article. First, while we are focused on Colombia, the impact of this militarized war on drugs extends to other Latin American nations. In the 1990s, the US spent more than $\$ 500$ billion attempting to immobilize the drug trade forcing illicit crops to the most ecologically fragile lands in Peru, Bolivia and Colombia: the Andean rainforest (Burke 2003; see also Count the Costs 2011). Second, it is essential to plan for remediation in the wake of this war. While challenging in many respects, removing economic incentives for growing crops (whether legal or illegal) would reduce the rates of deforestation and encourage farmers and citizens to invest in improvements in land already being cultivated (Alvarez 2002; Davalos et al. 2009; Davalos et al. 2011). For the sake of fairness and to promote durable social institutions, it will be essential to provide social and legal assistance to indigenous peoples (Young 2004) as they seek to recover from the adverse effects of this drug war.
} 


\section{Conclusion}

Colombia faces formidable environmental challenges: deforestation, declining biodiversity, and degraded land and water. Colombia's challenges extend to the political and social realm to include failed economic policies, chronic poverty and unemployment, and overt and armed challenges to the Colombian government. The militarized war on drugs exacerbates these environmental, social and political crises. During its first ten years, Plan Colombia failed to stem the flow of illicit substances to the United States. Since 2010, it appears that coca cultivation and export of cocaine from Colombia has declined. Whether a final assessment concludes that Plan Colombia succeeded or failed to suppress cocaine exports to the United States, this militarized effort highlights the workings of the treadmill of destruction in the $21^{\text {st }}$ Century: diverse armed forces profit directly and indirectly from predatory relations with noncombatants and unsustainable environmental practices. These trends are amplified by the policies of global powers. The risks of militarism-social, political and environmental-are systematically transferred to and borne by the people, ecosystems and institutions of the Global South.

There are signs that Colombia's internal wars might recede. The Colombian government has met with FARC to negotiate an end to the war (Brodzinsky 2014). The nation's presidential election is becoming a referendum on these peace talks - to continue the incumbent's current negotiations or to embrace a more bellicose and punitive posture toward FARC (see BBC News 2013; International Crisis Group 2012; Maloney 2013). Even if we make optimistic assumptions (that the negotiations with FARC go well and that Colombia's role in coca and cocaine production recedes), Colombia's future and that of other Andean nations remains perilous. First, the "new" wars of the $21^{\text {st }}$ Century are notable for their concentration in countries with a prior history of conflict, and this has not always been the case. As late as the 1960s, the majority of civil wars took place in countries with no prior history of civil war. From 2000 to 2010, however, ninety percent $(90 \%)$ of all civil war onsets have occurred in nations with a prior conflict (Walter 2010). As is the case in Colombia, prolonged civil conflict undermine fragile social institutions, generate profound and long lasting grievances, and undermine the state's legitimacy. The people and places in greatest need for peace and development - the bottom billion (Collier 2008) - are likely to be in a war zone, recovering from a recent war and/or on the verge of another round of war. Second, suppressing coca cultivation and cocaine exports from Colombia does not guarantee an overall reduction in supply at the global level. Prior to 1980, Colombia trailed Peru and Bolivia in drug production (and by a wide margin). In what is referred to as the "balloon effect," as pressure was placed on drug production in these neighboring countries, Colombia's output increased many times over. As Colombian production has ebbed, Peru recently overtook Colombia and is now the largest producer and exporter of cocaine (Brodzinsky 2014). Further, using species better suited for lower altitude rainforests, coca cultivation now extends into the Amazon rainforest, including sites in Brazil (Duffy 2008). Even if one makes very optimistic assumptions about Colombia, the prospects that coca cultivation, cocaine manufacture, and militarized eradication efforts will continue to impose horrific suffering on the people and ecosystems in the region remain high.

In one important respect, Colombia is not a representative case of the "new" wars of the $21^{\text {st }}$ Century. Ethnic tensions have not been pronounced; genocidal policies have not been pursued. These tensions and social cleavages are all too common in $21^{\text {st }}$ Century wars (Kaldor 1999; Mann 2005; Wimmer 2013) - and they bring a very specific dynamics and challenges. However, in other respects, the Colombian case can be generalized. Specifically, Colombia's 
recent history provides a glimpse into dynamics where: (1) a state demonstrably lacks a monopoly over the means of coercion and has lost legitimacy in the eyes of many citizens, and (2) a wide array of non-state militarized groups establish predatory ties to a lucrative and illegal source of revenues, and (3) a prominent and affluent military power intervenes to amplify these dynamics while insulating its own troops and homeland from the human and environmental costs. In this context, the human suffering and human rights abuses are widespread and severe. With regard to environment damage, the consequences of the treadmill of destruction are alarming. Irresponsible production processes have been coupled with ecocidal eradication efforts to cause extensive damage to Colombia's water, soil and forests and has compromised entire ecosystems. In this way, Colombia exhibits several features of "catastrophic convergence" (Parenti 2011) and "linked crises" (Chase-Dunn 2013). Colombia faces years, perhaps decades, of environmental damage tied the cascade of multiple crises unfolding at once in a location where "new" war, illustrative of risk-transfer militarism, is commonplace. While this examination of Colombia's recent history offers preliminary insights, it will be important for researchers to continue studying war and its aftermath. And when doing so, it will be important to elucidate the distinctive drivers and dimensions of the treadmill of destruction.

\section{References}

Achard, Federic, Hugh D. Eva, Hans-Jurgen Stibig, Philippe Mayaux, Javier Gallego, Timothy Richards and Jean-Paul Malingeau. 2002. "Determination of Deforestation Rates of the World's Humid Tropical Forests." Science 297(5583): 999-1002.

Alvarez, Maria D. 2001b. "Could Peace Be Worse than War for Colombia's Forests?" The Environmentalist 21: 305-315.

Alvarez, Maria D. 2002. "Illicit Crops and Bird Conservation Priorities in Colombia." Conservation Biology 16(4): 1086-1096.

Armenteras, Dolors, Guillermo Rudas, Nelly Rodriguez, Sonia Sua, Milton Romero. 2006. "Patterns and Causes of Deforestation in the Colombian Amazon." Ecological Indicators 6: 353-368.

Armenteras, Dolors, Nelly Rodriguez, and Javier Retana. 2013. "Landscape Dynamics in Northwestern Amazonia: An Assessment of Pastures, Fire and Illicit Crops as Drivers of Tropical Deforestation." PLOS ONE 8(1): e54310.

Ballvé, Teo. 2013. "Grassroots Masquerades: Development, paramilitaries, and land laundering in Colombia." Geoforum 50:62-75.

Bagley, Bruce Michael. 1991. "Myths of Militarization: The Role of the Military in the War on Drugs in the Americas." Pp. 1-37 in Drug Trafficking in the Americas Series. Miami: North-South Center, University of Miami.

BBC News. 2013. "Colombia Peace Talks Resume in Cuba." London: BBC News. Retrieved online July 11, 2013 (http://www.bbc.co.uk/news/world-latin-america-22853611).

Benachour, Nora and Gilles-Eric Seralini. 2009. "Glyphosate Formulations Induce Apoptosis and Necrosis in Human Umbilical, Embryonic, and Placental Cells." Chemical Research in Toxicology 22: 97-105. 
Bejarano, Ana Maria and Eduardo Pizarro. 2005. "From 'Restricted' to 'Besieged': The Changing Nature of the Limits to Democracy in Colombia." Pp. 235-260 in The Third Wave of Democratization in Latin America: Advances and Setbacks, edited by $\mathrm{F}$. Hagopian and Scott P. Mainwaring. Cambridge: Cambridge University Press.

Bonds, Eric. 2013. "Hegemony and Humanitarianism Norms: The US Legitimization of Toxic Violence." Journal of World-Systems Research 19(1): 82-106.

Brodzinsky, Sibylla. 2014. "FARC Peace Talks May Tip Balance in Tight Colombian Presidential Race. The Guardian (May 22, 2014).

Brittain, James. 2010. Revolutionary Social Change in Colombia: The Origin and Direction of the FARC-EP. New York: Pluto Press.

Bunker, Stephen. 2005. "How Ecologically Uneven Developments Put the Spin on the Treadmill of Production." Organization Environment 18: 38-54.

Burke, Tom. 2003. "Warning: Drugs Cost the Earth." New Statesman 132: 31.

Buxton, Julia. 2006. The Political Economy of Narcotics: Production, Consumption and Global Markets. London/New York: Zed Books.

Chase-Dunn, Christopher. 2013. "Five Linked Crises in the Contemporary World-System." Journal of World-System Research 19(2): 175-181.

Ciccantell, Paul and David A. Smith. 2009. "Rethinking Global Commodity Chains: Integrating Extraction, Transport, and Manufacturing." International Journal of Comparative Sociology 50: 361-384.

Clark, Brett and Andrew K. Jorgenson. 2012. "The Tread*mill of Destruction and the Environmental Impacts of Militaries." Sociology Compass 6/7: 557-569.

Clelland, Donald. 2014. "The Core of the Apple: Dark Value and Degrees of Monopoly in Global Commodity Chains." Journal of World System Research 20:82-111.

Collier, Paul. 2008. The Bottom Billion: Why the Poorest Countries are Failing and What Can Be Done About It. New York: Oxford University Press.

Congressional Research Service. 2011. "Latin America and the Caribbean: Illicit Drug Trafficking and U.S. Counterdrug Programs." Retrieved July 11, 2013 (http://publicintelligence.net/latin-america-and-the-caribbean-illicit-drug-trafficking-andu-s-counterdrug-programs/).

Count the Costs. 2011. "The War on Drugs: Causing Deforestation and Pollution." Count the Costs Environment Briefing. Retrieved January 4, 2012 (http://countthecosts.org/sevencosts/deforestation-and-pollution).

Davalos, Liliana M., Adriana C. Bejarano, and H. Leonardo Corea. 2009. "Disabusing Cocaine: Pervasive Myths and Enduring Realities of a Globalized Commodity." International Journal of Drug Policy 20: 381-386.

Davalos, Liliana M., Adriana Bejarano, Mark A. Hall, H. Leonardo Correa, Angelique Corthals, and Oscar J. Espejo. 2011. "Forests and Drugs: Coca-Driven Deforestation in Tropical Hotspots." Environmental Science and Technology 45: 1219-1227.

De Liz Oliveira Cavalli, Vera, Daiane Cattani, Carla Elise Heinz Rieg, Paula Pierozan, Leila Zanatta, Eduardo Benedetti Parisotto, Danilo Wilhelm Filho, Fatima Regina Mena Barreto Silva, Regina Pessoa-Pureur, and Ariane Zamoner. 2013. "Roundup Disrupts Male Reproductive Function by Triggering Calcium-Mediated Cell Death in Rat Testis and Sertoli Cells." Free Radical Biology and Medicine 65: 335-346.

Dombey-Moore, Bonnie, Susan Resetar, and Michael Childress. 1994. A System Description of the Cocaine Trade. Santa Monin, CA; Rand Corporation. 
Dube, Oeindrila and Suresh Naidu. 2010. "Bases, Bullets, and Ballots: The Effect of U.S. Military Aid on Political Conflict in Colombia." Center for Global Development. Working Paper 197, Janurary 2010. Retrieved May 24, 2012 (http://www.cgdev.org/files/1423498 file Dube Naidu Military Aid FINAL.pdf).

Duffy, Gary. 2008. "First Coca Find in Brazil Amazon." BBC News. Retrieved May 25, 2014 (http://news.bbc.co.uk/2/hi/7299964.stm).

The Economist. 2013. "Why is Less Cocaine Coming from Colombia?" The Economist. Retrieved March 5, $2014 \quad$ (http://www.economist.com/blogs/economistexplains/2013/04/economist-explains-why-colombia-produces-less-cocaine).

Etter, Andres, Clive McAlpine, Kerrie Wilson, Stuart Phinn, Hugh Possingham. 2006. "Regional Patterns of Agricultural Land Use and Deforestation in Colombia." Agriculture, Ecosystems and Environment 114: 369-386.

Eraso, Nelly Rodriguez, Dolors Armenteras-Pascual, and Javier Retana Alumbreros. 2012. "Land Use and Land Cover Change in Colombian Andes: Dynamics and Future Scenarios." Journal of Land Use Science DOI: 10.1080: 1-21.

Fjeldsa, Jon, Maria D. Alvarez, Juan Mario Lazcano, and Blanca Leon. 2005. "Illicit Crops and Armed Conflict as Constraints on Biodiversity Conservation in the Andes Region." Ambio 34(3): 205-211.

Gasnier, Eline, Coraline Dumont, Nora Benachour, Emilie Clair, Marie-Christine Chagnon, and Gilles-Eric Seralini. 2009. "Glyphosate-base Herbicides are Toxic and Endocrine Disruptors in Human Cell Lines." Toxicology 262: 184-191.

Gould, Kenneth A., David N. Pellow, and Allan Schnaiberg. 2008. The Treadmill of Production: Injustices and Unsustainability in the Global Economy. Boulder, Colorado: Paradigm Publishers.

Guerrero Baron, Javier, and David Mond. 2001 "Is the War Ending? Premises and Hypotheses with Which to View the Conflict in Colombia." Latin American Perspectives 28(1): 1230 .

Hellin, Jon. 2001. "Coca Eradication in the Andes: Lessons from Bolivia." Capitalism Nature Socialism 12(2): 139-57.

Holmes, Jennifer S., Gutierrez De Pineres, Sheila Amin, and Kevin M. Curtain. Guns, Drugs, and Development in Colombia. Austin, Texas: University of Texas Press.

Hooks, Gregory, and Chad L. Smith. 2004. "The Treadmill of Destruction: National Sacrifice Areas and Native Americans." American Sociological Review 69:558-76.

---. 2005. "Treadmills of Production and Destruction: Threats to the Environment Posed by Militarism." Organizations and Environment 18:19-37.

----. 2012. "The Treadmill of Destruction Goes Global: Anticipating the Environmental Impact of Militarism in the $21^{\text {st }}$ Century." Pp. 60-83 in The Marketing of War in the Age of NeoMilitarism, edited by Kostas Gouliamos and Christos Kassimeris. Routledge Press.

Hopkins, Terence and Wallerstein, Immanuel 1982. World-Systems Analysis: Theory and Methodology. Beverly Hills, CA: Sage.

Hough, Phillip. 2011. "Guerrilla Insurgency as Organized Crime: Explaining the So-Called 'Political Involution' of the Revolutionary Armed Forces of Colombia." Politics \& Society 39: 379-414.

Inter-American Drug Abuse Control Commission (CICAD, OAS). 2005. The Toxicology of Selected Chemicals Used in the Production and Refining of Cocaine and Heroin: A Tier- 
two Assessment (D 2005-01). Washington, DC: Inter-American Drug Abuse Control Commission (CICAD), Organization of American States.

International Crisis Group. 2005. War and Drugs in Colombia (Latin America Report $\mathrm{N}^{\circ} 11$ ).

Brussels: International Crisis Group. Retrieved July 11, 2013 (http://www.crisisgroup.org/en/regions/latin-america-caribbean/andes/colombia/011-warand-drugs-in-colombia.aspx).

International Crisis Group. 2012. "Colombia: Peace at Last?" Executive Summary and Recommendations. Brussels: International Crisis Group. Retrieved July 11, 2013 (http://www.crisisgroup.org/en/regions/latin-america-caribbean/andes/colombia/045colombia-peace-at-last.aspx).

Jasper, Raquel, Gabriel Olivo Locatelli, Celso Pilati, and Claudriana Locatelli. 2012. "Evaluation of Biochemical, Hematological and Oxidative Parameters in Mice Exposed to the Herbicide Glyphosate-Roundup ${ }^{\circledR} . "$ Interdisciplinary Toxicology 5(3): 133-140.

Jorgenson, Andrew. 2005. "Unpacking International Power and the Ecological Footprints of Nations: A Quantitative Cross-National Study." Sociological Perspectives 48:383-402.

Jorgenson, Andrew and Brett Clark. 2009. "The Economy, Military, and Ecologically Unequal Relationships in Comparative Perspective: A Panel Study of the Ecological Footprints of Nations, 1975-2000." Social Problems 56:621-646.

Jorgenson, Andrew, Brett Clark, and Jeffrey Kentor. 2010. "Militarization and the Environment: A Panel Study of Carbon Dioxide Emissions and the Ecological Footprints of Nations, 1970-2000." Global Environmental Politics 10:7-29.

Kaldor, Mary. 1999. New and Old Wars: Organized Violence in a Global Era. Stanford, CA: Stanford University Press.

Leitenberg, Milton. 2006. "Deaths and Wars in Conflicts in the $20^{\text {th }}$ Century." Ithaca, NY: Cornell University, Peace Studies Program. Retrieved May 22, 2012 (http://www.clingendael.nl/publications/2006/20060800 cdsp occ leitenberg.pdf).

Lengefeld, Michael and Chad L. Smith. 2013. "Nuclear Shadows: Weighing the Environmental Effects of Militarism, Capitalism, and Modernization in a Global Context, 2001-2007." Human Ecology Review 20(1): 11-25.

Mabry, Donald. 1988. "The US Military and the War on Drugs in Latin America." Journal of Interamerican Studies and World Affairs 30(2/3): 53-76.

Maloney, Anastasia. 2013. "Ten Things You Didn't Know about Colombia's Peace Talks."

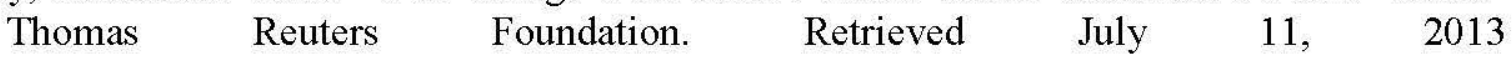
(http://www.trust.org/item/20130705105455-b396j).

Mann, Michael. 2005. The Dark Side of Democracy: Explaining Ethnic Cleansing. New York: Cambridge University Press.

Mejía, Daniel, and Carlos Posada. 2008. Cocaine Production and Trafficking: What Do We Know? (Policy Research Working Paper 4618). Washington, DC: World Bank.

Messina, J. P. and P.L. Delamater. 2006. "Defoliation and the War on Drugs in Putumayo, Colombia." International Journal of Remote Sensing 27(1): 121-128.

Meza-Joya, Fabio Leonardo, Martha Patricia Ramirez-Pinilla, and Jorge Luis Fuentes-Lorenzo. 2013. "Toxic, Cytoxic, and Genetoxic Effects of a Glyphosate Formulation (Roundup ${ }^{\circledR S L-C o s m o f l u x}{ }^{\circledR} 411 \mathrm{~F}$ ) in the Direct-Developing Frog Eleutherodactylus johnstonei." Environmental and Molecular Mutagenesis 54: 362-373. 
Mugge, Zachary. 2004. "Plan Colombia: The Environmental Effects and Social Costs of the United States' Failing War on Drugs." Colorado Journal of International Environmental Law and Policy 15(2): 309-340.

Nobre, Carlos, Piers J. Sellers, Jagadish Shukla. 1991. "Amazonian Deforestation and Regional Climate Change" Journal of Climate 4: 956-988.

Office of National Drug Control Policy. 2012. "Survey Shows Significant Drop in Cocaine Production in Colombia." Retrieved August 1, 2012 (http://www.whitehouse.gov/ondcp/news-releases-remarks/survey-shows-significantdrop-in-cocaine-production-in-colombia).

Peceny, Mark and Michael Durnan. 2006. "The FARC's Best Friend: U.S. Antidrug Policies and the Deepening of Colombia's Civil War in the 1990s." Latin American Politics and Society 48(2): 95-116.

Parenti, Christian. 2011. Tropic of Chaos: Climate Change and the New Geography of Violence. New York: Nation Books.

Priest, Dana. 2013. Washington Post. "Covert Action in Colombia." Retrieved January 1, 2013 (http://www.washingtonpost.com/sf/investigative/2013/12/21/covert-action-in-colombia/).

Relyea, Rick A. 2005a. "The Impact of Insecticides and Herbicides on the Biodiversity and Productivity of Aquatic Communities." Ecological Applications 15(2): 618-627.

Relyea, Rick A. 2005b. "The Lethal Impact of Roundup on Aquatic and Terrestrial Amphibians." Ecological Applications 15(4): 1118-1124.

Relyea, Rick A. 2011. "Amphibians Are Not Ready for Roundup®." Pp. 267-300 in Wildlife Ecotoxicology: Forensic Approaches, edited by J.E. Elliot, C.A. Bishop, and C. Morrisey. New York: Springer.

Ribot, Jesse. 1998. "Theorizing Access: Forest Profits along Senegal's Charcoal Commodity Chain." Development and Change 29: 307-41.

Rice, James. 2007. "Ecological Unequal Exchange: Consumption, Equity, and Unsustainable Structural Relationships within the Global Economy." International Journal of Comparative Sociology 48: 43-72.

Ronderos, Juan G. 2003. "The War on Drugs and the Military: The Case of Colombia." Pp. 207236 in Critical Reflections on Transnational Organized Crime, Money Laundering, and Corruption, edited by Margaret E. Beare. Toronto: University of Toronto Press.

Saab, Bilal Y. and Alexandra W. Taylor. 2009. "Criminality and Armed Groups: A Comparative Study of FARC and Paramilitary Groups in Colombia." Studies in Conflict \& Terrorism 32: 455-475.

Samsel, Anthony and Stephanie Seneff. 2013. "Glyphosate's Suppression of Cytochrome P450 Enzymes and Amino Acid Biosynthesis by the Gut Microbiome: Pathways to Modern Diseases." Entropy 15: 1416-1463.

Schnaiberg, Allan. 1980. The Environment: From Surplus to Scarcity. New York: Oxford University Press.

Schnaiberg, Allan and Kenneth A. Gould. 1994. Environment and Society: The Enduring Conflict. New York: St. Martin's Press.

Scott, Peter Dale. 2003. Drugs, Oil and War: The United States in Afghanistan, Colombia, and Indochina. Lanham, Maryland: Rowman and Littlefield.

Shandra, John M., Christopher Leckband and Bruce London. 2009. "Ecologically Unequal Exchange and Deforestation: A Cross-National Analysis of Forestry Export Flows." Organization \& Environment 22(3): 293-310. 
Shaw, Martin. 2002. "Risk-Transfer Militarism: Small Massacres and the Historic Legitimacy of War." International Relations 16:343-60.

----. 2005. The New Western Way of War: Risk-Transfer War and Its Crisis in Iraq. Cambridge, UK: Polity.

Solomon, Keith, Arturo Anadon, Gabriel Carrasquilla, Antonio L. Cerdeira, Jon Marchall, and Luz-Helena Sanin. 2007. "Coca and Poppy Eradication in Colombia: Environmental and Human Health Assessment of Aerially Applied Glyphosate." Reviews of Environmental Contamination and Toxicology 190: 43-125.

Solomon, Keith, E.J.P Marshall, and Gabriel Carrasquilla. 2009. "Human Health and Environmental Risks from the Use of Glyphosate Formulations to Control the Production of Coca in Colombia: Overview and Conclusions." Journal of Toxicology and Environmental Health, Part A 72: 914-920.

Stokes, Doug. 2001. "Better Lead than Bread? A Critical Analysis of the US's Plan Colombia." Civil Wars 4(2): 59-78.

Stokes, Doug. 2005. America's Other War: Terrorizing Colombia. New York: Zed Books.

Summerfield, Derek. 1991. "The Psychosocial Effects of Conflict in the Third World." Development in Practice. 1(3): 159-173.

Tenenbaum, David. 2002. "Coca-Killing Controversy." Environmental Health Perspectives 110(5): A236.

Thongprakaisang, Siriporn, Apinya Thiantanawat, Nuchanart Rangkadilok, Tawit Suriyo, and Jutamaad Satayavivad. 2013. "Glypohsate Induces Human Breast Cancer Cells Growth Via Estrogen Receptors." Food and Chemical Toxicology 59: 129-136.

Tilly, Charles. 1975. "Reflections on the History of European State-Making." Pp. 3-83 in The Formation of National States in Western Europe, edited by Charles Tilly. Princeton: Princeton University Press.

Transnational Institute. 2001. "Vicious Circle: The Chemical and Biological "War on Drugs."" $\begin{array}{lllll}\text { Transnational Institute Report. } & \text { Retrieved }\end{array}$ (http://www.tni.org/sites/www.tni.org/files/download/viciouscircle-e.pdf).

United Nations, Office of the High Commissioner for Human Rights. 2010. "Briefing 6: Human Rights and Drug Policy: Crop Eradication." New York: United Nations Retrieved May 25, 2012 (http:/www2.ohchr.org/english/bodies/cescr/docs/ngos/IHRA Colombia44.pdf).

United Nations, Office on Drugs and Crime. 2010. World Drug Report 2010. New York: United $\begin{array}{llll}\text { Nations. } & \text { Retrieved } & \text { March } & 514\end{array}$ (http://www.unodc.org/documents/wdr/WDR 2010/World Drug Report 2010 lores.pdf).

----. 2012a. "Colombia Coca Cultivation Survey 2011." New York: United Nations. Retrieved August $\quad 1, \quad 2012 \quad$ (http://www.unodc.org/documents/cropmonitoring/Colombia/Colombia_Coca_cultivation_survey 2011.pdf).

----. 2012b. "Colombia Grows Quarter Less Coca Crop, According to UNODC 2012 Survey." New York: United Nations. Retrieved March 5, 2014 (http:/www.unodc.org/unodc/en/frontpage/2013/August/colombia-grows-quarter-lesscoca-crop-according-to-unodc-2012-survey.html).

United Nations, Human Rights Council. 2013. "Universal Periodic Review: National report submitted in accordance with paragraph 5 of the annex to Human Rights Council resolution 16/21." New York: United Nations. Retrieved January 13, 2013 
(http://www.ohchr.org/Documents/HRBodies/HRCouncil/RegularSession/Session23/TF/ A-HRC-RES-16-21 en.doc).

United States Department of State. 2002. "Chemicals Used for the Aerial Eradication of Illicit Coca in Colombia and Conditions of Application." Retrieved August 8, 2013 (http://www.state.gov/j/inl/rls/rpt/aeicc/13234.htm).

United States Department of State. 2003. "Environmental Consequences of the Illicit Coca Trade." Retrieved May 25, 2012 (http://2001-2009.state.gov/p/inl/rls/fs/3807.htm).

Vaicius, Ingrid and Adam Isacson. 2003. "The 'War on Drugs' meets the 'War on Terror:' The United States' Military Involvement in Colombia Climbs to the Next Level." International Policy Report. Retreived May 29, 2012 (http://www.ciponline.org/images/uploads/publications/0302ipr.pdf).

Walter, Barbara. 2010. Conflict Relapse and the Sustainability of Post-Conflict Peace (World Development Report 2011: Background Paper). Washington, D.C.: World Bank. Retrieved February 25, 2014 (https://openknowledge.worldbank.org/bitstream/handle/10986/9069/WDR201 1_0008.pdf? sequence=1).

Wickham-Crowley, Timothy P. 1992. Guerrillas \& Revolution in Latin America: A Comparative Study of Insurgents and Regimes Since 1956. Princeton, New Jersey: Princeton University Press.

Wimmer, Andreas. 2013. Waves of War: Nationalism, State Formation, and Ethnic Exclusion in the Modern World. New York: Cambridge University Press.

York, Richard. 2008. "De-carbonization in Former Soviet Republics, 1992-2000: The Ecological Consequences of De-modernization." Social Problems 55:370-390.

Young, Kenneth R. 2004 "A Geographical Perspective on Coca/Cocaine Impacts in South America." Pp. 363-367 in WorldMinds: Geographical Perspectives on 100 Problems, edited by Donald G. Janelle, Barney Warf, and Kathy Hansen. The Netherlands; Kluwer Academic Publishers. Retrieved April 22, 2012 (http://books.google.com/books?hl=en\&lr=\&id=0VxzNOj7feEC\&oi=fnd\&pg=PA363\&d $\mathrm{q}=$ Threats + to + Biological + Diversity + Caused $+\mathrm{by}+\mathrm{Coca} /$ Cocaine + Deforestation + in + Peru \&ots $=\mathrm{WCO} 2$ beKXH\&sig= $\mathrm{OW}$ lg-w0R41 lwr2HpE1KzB5Eg\# $\mathrm{v}=$ onepage\& $\mathrm{q}=$ Threats $\% 20$ to $\% 20$ Biological $\% 20$ Diversity $\% 20$ Caused $\%$ $20 \mathrm{by} \% 20 \mathrm{Coca} \% 2 \mathrm{FCocaine} \% 20$ Deforestation $\% 20$ in $\% 20$ Peru\&f=false).

Zirnite, Peter. 1997. "Reluctant Recruits: The US Military and the War on Drugs." Washington Office on Latin America (WOLA), Transnational Institute Report, Retrieved March 25, 2012(http://www.tni.org/sites/www.tni.org/files/download/Reluctant\%20recruits\%20repo rt 0.pdf). 